\title{
Impact of headache on a supplemental healthcare emergency unit and on use of opioids
}

\author{
Impacto das cefaleias em unidade de emergência da saúde suplementar e o uso de \\ opioides
}

\author{
Aline VITALI DA SILVA',2, Letícia Mayumi CARVALHO KIY1', Caroline de Almeida ALVES ${ }^{1}$, Gabriela Cristina \\ KIRYLKO', Valéria Aparecia BELLO', Regina Célia POLI-FREDERICO'
}

\begin{abstract}
Background: Headache is one of the most common causes of emergency care and migraines are the most common primary headache in this regard. Objective: The aim of this research study was to assess the incidence of medical consultations due to headache, along with demographic characteristics and treatments pertaining to cephalalgia that were offered to patients cared for in supplemental healthcare emergency rooms. Methods: In 2017, a total of 11,105 consultations took place, and 4,865 (43.8\%) of them were complaints relating to headache. 407 records of patients with headache were randomly selected and assessed. Demographic, clinical and therapeutic data were collected using a structured form. Results: The cause of headache was diagnosed as migraine in $60.0 \%$ of the patient records. Patients were mostly female $(75.2 \%)$, with an average age of $33.9 \pm 13.7$ years. Patient management consisted of administering dipyrone in $62.4 \%$ of cases, antiemetics in $66.9 \%$, corticosteroids in $58.9 \%$, opioids in $24.3 \%$ and NSAIDs in $13.5 \%$. Use of opioids was associated with a diagnosis of migraine (OR 2.4; $\mathrm{Cl} 1.4-3.9 ; \mathrm{p}=0.001)$. Patients who received opioids were kept under observation for longer periods of time (OR 3.4; $\mathrm{Cl} 2.1-5.4 ; \mathrm{p}<0.001$ ) and exhibited a higher rate of use of antiemetics (OR 11.0; $\mathrm{Cl} 4.7-25.9 ; \mathrm{p}<0.001$ ), compared with patients who did not receive opioids. Conclusion: Dipyrone and antiemetics were administered to most of the patients. Opioids were used for a significant proportion of these individuals, despite the diagnosis of migraine, a condition for which their use is discouraged.
\end{abstract}

Keywords: headache; migraine; opioid; emergency department.

\section{RESUMO}

Introdução: Cefaleia é uma das causas mais frequentes de atendimentos de emergência, sendo que a migrânea é a cefaleia primária mais comum nesse contexto. Objetivo: Avaliar a frequência de atendimentos por cefaleias, bem como as características demográficas e o tratamento oferecido aos pacientes atendidos em Pronto Atendimento da Saúde Suplementar. Métodos: No ano de 2017 foram realizados 11.105 atendimentos, sendo 4.865 (43,8\%) por queixa de cefaleia. Foram selecionados randomicamente a analisados 407 prontuários de pacientes com cefaleia. Os dados demográficos, clínicos e terapêuticos foram coletados através de formulário estruturado. Resultados: A causa da cefaleia foi diagnosticada como migrânea em 60,0\% dos prontuários. Os pacientes eram em sua maioria do sexo feminino (74,9\%), com média de idade de 33,9 913,7 anos. 0 manejo dos pacientes constitui-se na administração de dipirona em $62,4 \%$, antiemético $66,9 \%$; corticóide 58,9\%, opióide 24,3\% e, por fim, AINE foi utilizado em 13,5\% dos casos. 0 uso de opióide foi associado ao diagnóstico de migrânea (OR 2,4; Cl 1,4-3,9; p=0,001). Pacientes que receberam opióide também tiveram maior tempo de permanência (OR 3,4; IC 2,15,$4 ; p<0,001$ ) e maior taxa de uso de antiemético (OR 11,0; Cl 4,7-25,9; p<0,001), quando comparados aos pacientes que não receberam opióides. Conclusão: Dipirona e antiemético foram administrados na maioria dos pacientes. Opióide foi utilizado em parcela importante de indivíduos a despeito do diagnóstico de migrânea, condição na qual seu uso é desaconselhado.

Palavras-chave: cefaleia; migrânea; opióde; serviço de emergência.

\footnotetext{
'Pontifícia Universidade Católica do Paraná, Londrina PR, Brazil.

${ }^{2}$ Pronto Atendimento Unimed Londrina, Londrina PR, Brazil.

Aline VITALI DA SILVA (D) https://orcid.org/0000-0001-7797-9227; Letícia Mayumi CARVALHO KIY (D) https://orcid.org/0000-0002-9669-8903; Caroline de Almeida ALVES (D) https://orcid.org/0000-0002-0579-7608; Gabriela Cristina KIRYLKO (iD https://orcid.org/0000-0003-4123-2230; Valéria Aparecia BELLO (1D https://orcid.org/0000-0001-7919-6218; Regina Célia POLI-FREDERICO (D) https://orcid.org/0000-0003-4631-4606 Correspondence: Aline Vitali da Silva; Email: alinevitalidasilva@gmail.com.

Conflict of interest: There is no conflict of interest to declare.
}

Authors' contributions: AVS, LMC, CAA, GCK: contributed to the design and implementation of the research; AVS, VAB, RCPF: contributed to the analysis of the results and to the writing of the manuscript.

Received on May 15, 2020; Received in its final form on September 30, 2020; Accepted on October 05, 2020. 


\section{INTRODUCTION}

Headache is one of the most common symptoms in medical practice and has a significant impact on the population's quality of life and on the healthcare system. The prevalence of headache in the Brazilian population over a one-year period has been estimated to be $70.6 \%$, of which $15.8 \%$ results from migraine ${ }^{1}$.

Migraine is a disorder distinguished by recurring episodes of cephalalgia. The most acute of these episodes are treated by means of painkillers and antiemetics, with potential supplementation with triptans, ergotamine, corticosteroids and antipsychotics, depending on the seriousness and evolution of the condition. Administration of opioids is emphatically not recommended, due to the high rate of adverse events and low effectiveness of this scenario ${ }^{2}$.

Headache is the fifth most common cause of emergency care in the United States, corresponding to 3\% of all emergency consultations ${ }^{3}$. In Brazil, headache is the fourth most common cause of incapacity for normal activities, and is one of the main causes of absenteeism and presenteeism.

Few studies have explored emergency care due to cephalalgia in Brazil ${ }^{4}$. The aim of the present study was to assess the frequency of emergency care due to headache, included migraine, along with the demographic characteristics and treatment offered.

\section{METHODS}

This was a retrospective observational study comprising patients seen in a supplemental healthcare emergency care unit (ECU) in the city of Londrina, Paraná, Brazil.

ECUs provide an emergency service for cases of low-tomedium complexity. They operate 24 hours a day and do not have an inpatient department. The health insurance company responsible for the ECU of the present study is a medical cooperative that runs on supplemental health plans and is responsible for 187,621 lives in Londrina and its surrounding area.

The present study comprised patients seen mainly with headache-related complaints that were classified in ICD-10 as G43, G44 and R51, from January 1 to December 31, 2017. Patients with incomplete records were excluded. Stratified random sampling was performed using the formula proposed by Barbetta ${ }^{5}$, taking the months of the year into account: $7.2 \%$ in January; $7.1 \%$ in February; 9.4\% in March; $8.6 \%$ in April; 9.7\% in May; $8.5 \%$ in June; $7.5 \%$ in July; $6.9 \%$ in August; $8.6 \%$ in September; $9.2 \%$ in October; $8.9 \%$ in November; and $7.7 \%$ in December. Out of the total population of 4,865 patients with headache who were seen in the ECU, the minimum sample size required was 407 patients.

Data collection was performed via a review of electronic records and used a standardized collection instrument, which included data on demographic variables, consultations and clinical variables. The demographic variables collected were age, sex, marital status and occupation. The consultation data included: shift within which the patient arrived, duration of patient care, medication used and diagnosis recorded.

The headache diagnosis was taken to be as entered in the specific field of the electronic medical record that was completed by the emergency physician. The diagnoses were classified as (1) migraine, (2) tension-type headache, (3) headache attributed to systemic infection or acute rhinosinusitis, (4) suspected headache attributed to intracranial disorder or (5) unspecified headache.

The present study was conducted after approval by the Research Ethics Committee of the Pontifical Catholic University of Paraná (Pontifícia Universidade Católica do Paraná), under the number 2.907.263. All the researchers involved agreed to maintain confidentiality regarding the data collected, as well as privacy and confidentiality of the data content, as advocated in international documents and through Brazilian Ministry of Health Resolutions 510/2016 and 466/2012. To this end, the required data usage agreement was signed.

Categorical data were assessed via Fisher's exact test or the chi-square test, as appropriate. For assessment of continuous variables, Student's t test was used, and these results were shown as means and standard deviations. The analyses were performed using the statistical program SPSS, version 20.0. A confidence interval of $95 \%$ and a significance level of $5 \%(\mathrm{p}<0.05)$ were used for all tests applied.

\section{RESULTS}

A total of 11,105 consultations took place at this ECU between January 1 and December 31, 2017. Among these,4,865 cases mainly comprised complaints of headache, which thus corresponded to $43.80 \%$ of all the cases. From among these consultations for headache, 407 records were randomly selected and analyzed.

The patients were mostly female $(74.9 \%)$, with an average age of $33.9 \pm 13.7$ years. There was no statistically significant difference in age between the sexes. Regarding marital status, $50.6 \%$ were single, $44.2 \%$ were married, $4.2 \%$ were divorced and $1 \%$ were widowers. There was no difference between the sexes regarding marital status $(p=0.132)$. Occupational information was available for 324 patients; students formed the largest proportion (18.5\%), followed by administrative/ accounting assistants, salespeople and healthcare professionals, with $13.0 \%, 10.5 \%$ and $9.9 \%$, respectively (Table 1).

Most consultations occurred in the daytime, during the morning shift (31.4\%) or afternoon shift (35.4\%). Most patients remained in the ECU for less than two hours (62.4\%), as shown in Table 1. 
Table 1. Demographic characteristics, measurement of length of consultation time and status of migraine diagnosis among individuals seen with a complaint of headache in an emergency unit in the supplemental healthcare network.

\begin{tabular}{|c|c|c|c|c|c|}
\hline & & $\begin{array}{l}\text { Females } \\
\mathrm{N}=305\end{array}$ & $\begin{array}{c}\text { Males } \\
N=102\end{array}$ & $\begin{array}{c}\text { Total } \\
\mathrm{N}=407\end{array}$ & $\mathrm{p}$ \\
\hline \multicolumn{2}{|c|}{ Age, years (mean \pm SD) } & $34.1 \pm 12.7$ & $33.5 \pm 16.5$ & $33.9 \pm 13.7$ & 0.703 \\
\hline \multirow{4}{*}{ Marital status } & Single & $146(47.9 \%)$ & $60(58.2 \%)$ & $206(50.6 \%)$ & \multirow{4}{*}{0.137} \\
\hline & Married & $140(45.9 \%)$ & $40(39.2 \%)$ & $180(44.2 \%)$ & \\
\hline & Widower & $4(1.3 \%)$ & $0(0.0 \%)$ & $4(1.0 \%)$ & \\
\hline & Divorced & $15(4.9 \%)$ & $2(2.0 \%)$ & $17(4.2 \%)$ & \\
\hline \multirow{4}{*}{ Profession } & Student & $47(18.9 \%)$ & $13(17.3 \%)$ & $60(18.5 \%)$ & \multirow{4}{*}{$<0.001$} \\
\hline & $\begin{array}{c}\text { Administrative/accounting } \\
\text { assistant }\end{array}$ & $38(15.3 \%)$ & $4(5.3 \%)$ & $42(13.0 \%)$ & \\
\hline & Sales & $19(7.6 \%)$ & $15(20.0 \%)$ & $34(10.5 \%)$ & \\
\hline & Healthcare professional & $32(12.9 \%)$ & $0(0.0 \%)$ & $32(9.9 \%)$ & \\
\hline \multirow{4}{*}{ Arrival time } & Morning (6:00-11:59) & $95(31.1 \%)$ & $34(33.3 \%)$ & $128(31.4 \%)$ & \multirow{4}{*}{0.014} \\
\hline & Afternoon (12:00-17:59) & $112(36.4 \%)$ & $33(32.4 \%)$ & $144(35.4 \%)$ & \\
\hline & Night (18:00-23:59) & $88(28.9 \%)$ & $23(22.5 \%)$ & $111(27.3 \%)$ & \\
\hline & Early morning (00:00-5:59) & $11(3.6 \%)$ & $12(11.8 \%)$ & $23(5.7 \%)$ & \\
\hline \multirow{4}{*}{ Length of stay } & Up to 59 minutes & $53(17.5 \%)$ & $26(25.5 \%)$ & $79(19.6 \%)$ & \multirow{4}{*}{0.032} \\
\hline & $60-119$ minutes & $125(41.4 \%)$ & $50(49.0 \%)$ & $175(43.4 \%)$ & \\
\hline & 120-209 minutes & $82(27.2 \%)$ & $19(18.6 \%)$ & $101(25.0 \%)$ & \\
\hline & More than 210 minutes & $42(13.9 \%)$ & $7(6.9 \%)$ & $49(12.1 \%)$ & \\
\hline \multirow{6}{*}{ Diagnosis } & Migraine & $201(65.9 \%)$ & $43(42.2 \%)$ & $244(60.0 \%)$ & \multirow{6}{*}{$<0.001$} \\
\hline & Tension-type headache & $16(5.2 \%)$ & $5(5.0 \%)$ & $21(5.2 \%)$ & \\
\hline & $\begin{array}{l}\text { Headache attributed } \\
\text { to systemic infection or } \\
\text { acute rhinosinusitis }\end{array}$ & $14(4.6 \%)$ & $15(24.9 \%)$ & $29(7.1 \%)$ & \\
\hline & $\begin{array}{c}\text { Headache attributed to } \\
\text { suspected intracranial } \\
\text { disorder }\end{array}$ & $3(1.0 \%)$ & $2(2.0 \%)$ & $5(1.2 \%)$ & \\
\hline & Other & $2(0.7 \%)$ & $2(2.0 \%)$ & $4(1.0 \%)$ & \\
\hline & Unspecified headache & $69(22.6 \%)$ & $35(34.3 \%)$ & $104(25.6 \%)$ & \\
\hline
\end{tabular}

The cause of headache was diagnosed as migraine in $60.0 \%$ of the cases. The prevalence of migraine was higher among females (65.9\%) than among males (42.2\%), with a statistically significant difference between the sexes (Table 1). Other headache diagnoses are presented in Table 1.

Patient management mainly consisted of administration of dipyrone, for $62.4 \%$ of the patients. With regard to other drugs, antiemetics were prescribed for $66.9 \%$ of the patients, followed by corticosteroids, which were used for $59.0 \%$ of the individuals, opioids, which were administered to $24.3 \%$ and lastly, NSAIDs, which were used in $13.5 \%$ of the cases. Only nine individuals received chlorpromazine. In the institution examined in this study, triptans and dihydroergotamine are not routinely prescribed.

Use of opioids was associated with a diagnosis of migraine (OR 2.4; CI 1.4-3.9; $\mathrm{p}=0.001$ ). Among the patients diagnosed with migraine, $30.3 \%$ received opioids. Table 2 shows the distribution of opioid use for other headaches. Patients who received opioids also remained in the ECU for longer than 120 minutes (OR 3.4; CI 2.1-5.4; $\mathrm{p}<0.001$ ) and had higher rates of use of corticosteroids (OR 1.8; CI 1.1-3.0; $\mathrm{p}=0.013$ ) and antiemetics (OR 11.0; CI 4.7-25.9; $\mathrm{p}<0.001$ ), compared with patients who did not receive opioids. In contrast, patients treated with opioids received dipyrone less often (OR 0.3; CI $0.2-0.5 ; \mathrm{p}<0.001)$. There was no difference in age, sex, arrival time or use of NSAIDs, between patients who did or did not receive opioids (Table 2).

Most of the patients seen were discharged after the consultation or after receiving medication. Only five patients were referred to tertiary-level hospitals. The medications most prescribed upon discharge were simple painkillers (paracetamol or dipyrone, separately or in combination) to 115 individuals (28.3\%); followed by NSAIDs, to 80 (19.6\%); dihydroergotamine, to 67 (16.5\%); triptans, to 41 (10.0\%); and opioids, to 38 (9.3\%). 
Table 2. Comparison of demographic, clinical and consultation variables among patients who received opioids and those who did not.

\begin{tabular}{|c|c|c|c|c|c|}
\hline & & $\begin{array}{l}\text { Without opioids } \\
\qquad N=308\end{array}$ & $\begin{array}{l}\text { With opioids } \\
\qquad N=99\end{array}$ & $\begin{array}{c}\text { Total } \\
N=407\end{array}$ & $p$ \\
\hline Age, years (mean \pm SD) & $33.4 \pm 14.3$ & $35.9 \pm 11.9$ & $33.9 \pm 13.7$ & 0.114 & \\
\hline \multirow{2}{*}{ Sex } & Female & $229(74.4 \%)$ & $76(76.8 \%)$ & $305(74.9 \%)$ & \multirow{2}{*}{0.629} \\
\hline & Male & $79(25.6 \%)$ & $23(23.2 \%)$ & $102(25.1 \%)$ & \\
\hline \multirow{4}{*}{ Arrival time } & Morning (6:00-11:59) & $96(31.2 \%)$ & $33(33.3 \%)$ & $129(31.7 \%)$ & \multirow{4}{*}{0,554} \\
\hline & Afternoon (12:00-17:59) & $113(36.7 \%)$ & $32(32.3 \%)$ & $144(35.4 \%)$ & \\
\hline & Night (18:00-23:59) & $84(27.3 \%)$ & $27(27.3 \%)$ & $111(27.3 \%)$ & \\
\hline & Early morning (00:00 - 5:59) & $15(4.9 \%)$ & $8(8.1 \%)$ & $23(5.7 \%)$ & \\
\hline \multirow{4}{*}{ Length of stay } & Up to 59 minutes & $70(22.9 \%)$ & $9(9.2 \%)$ & $79(19.6 \%)$ & \multirow{4}{*}{$<0.001$} \\
\hline & 60-119 minutes & $144(47.1 \%)$ & $31(31.6 \%)$ & 175 (43.4\%) & \\
\hline & 120-209 minutes & $65(21.2 \%)$ & $36(36.7 \%)$ & $101(25.0 \%)$ & \\
\hline & More than 210 minutes & $27(8.8 \%)$ & $22(22.4 \%)$ & $49(12.1 \%)$ & \\
\hline \multirow{6}{*}{ Diagnosis } & Migraine & $170(55.2 \%)$ & $74(74.7 \%)$ & $244(60.0 \%)$ & \multirow{6}{*}{$<0.001$} \\
\hline & Tension-type headache & $21(6.8 \%)$ & $0(0.0 \%)$ & $21(5.2 \%)$ & \\
\hline & $\begin{array}{l}\text { Headache attributed to } \\
\text { systemic infection or acute } \\
\text { rhinosinusitis }\end{array}$ & $26(8.5 \%)$ & $3(3.0 \%)$ & $29(7.1 \%)$ & \\
\hline & $\begin{array}{c}\text { Headache attributed to } \\
\text { suspected intracranial } \\
\text { disorder }\end{array}$ & $4(1.3 \%)$ & $1(1.0 \%)$ & $5(1.2 \%)$ & \\
\hline & Other & $1(0.3 \%)$ & $3(3.0 \%)$ & $4(1.0 \%)$ & \\
\hline & Unspecified headache & $86(27.9 \%)$ & $18(18.2 \%)$ & $104(25.6 \%)$ & \\
\hline Dipyrone & $212(68.8 \%)$ & $42(42.4 \%)$ & $254(62.4 \%)$ & $<0.001$ & \\
\hline NSAID & $48(16.6 \%)$ & $7(7.1 \%)$ & $55(13.5 \%)$ & 0.098 & \\
\hline Corticosteroid & $171(55.5 \%)$ & $69(69.7 \%)$ & $240(59.0 \%)$ & 0.013 & \\
\hline Antiemetic & $180(58.4 \%)$ & $91(93.8 \%)$ & $271(66.9 \%)$ & $<0.001$ & \\
\hline
\end{tabular}

NSAID: nonsteroidal anti-inflammatory drug.

\section{DISCUSSION}

This study assessed occurrences of headache and described the demographic, clinical and therapeutic profile of patients seen at the ECU of a supplemental healthcare emergency service in the city of Londrina.

Several studies have shown that patients with cephalalgia account for $3 \%$ of medical consultations in emergency care units, thus making it the fifth most common reason for consultations in emergency units ${ }^{3}$. In this study, a considerably greater frequency was observed, such that headache accounted for $43.8 \%$ of the consultations. This finding was possibly due to the fact that this ECU is a secondary-level care unit with spontaneous demand, which deals with cases of low-to-medium complexity. Non-complicated migraine, which accounted for the majority of the cases of headache, only requires basic resources for care, hence the high demand for this type of consultation.

The patients were mostly young females, as is the case with migraine in the general population. The men who sought care were younger than the women and there was no difference in the frequency of diagnosis of migraine between the sexes. The majority (58.5\%) were diagnosed by emergency doctors, and this was very similar to findings in other geographical regions ${ }^{6,7}$.

The medication most commonly administered was dipyrone, followed by antiemetics and corticosteroids. Despite the recommendations of the Brazilian Headache Society and the International Headache Society ${ }^{2,8}$, which advise against use of opioids for migraine, these drugs were used for $30.2 \%$ of the individuals diagnosed. Moreover, those who received opioids were twice as likely to experience migraine. Excessive use of opioids does not occur only in the Brazilian population. A 2017 study in the United States showed that the rate of opioid use among individuals with migraine was $35.8 \%$. In contrast, an academic medical center accounted for the lowest rate of opioid use, with only $6.9 \%$ of the patients receiving opioids. It is believed that the teaching environment facilitates the practice of adherence to the recommendations of the specialist societies?.

Patients who received opioids had a 3.4-fold greater chance of remaining under observation for more than 120 minutes, a 
finding that had already been observed in the American population ${ }^{10}$. Opioids are less effective against migraine than the recommended drugs ${ }^{11}$, which may explain the longer consultation times and higher rates of recurrence ${ }^{10}$.

Individuals exposed to opioids had a tenfold higher chance of receiving antiemetics than patients who were not exposed. A study on 147,832 patients showed that migraine patients who made use of opioids had a higher rate of adverse gastrointestinal effects like nausea and constipation, which might explain the greater use of antiemetics among the patients assessed ${ }^{12}$.

Interestingly, patients treated with opioids received dipyrone less often. Possibly the use of an effective pain relief medication for headache, such as dipyrone, may prevent opioid use.

This study had a limitation inherent to its design, whereby it was not possible to infer causality. It is possible that there may have been some bias related to incomplete records of clinical data. In addition, extrapolation to other populations may not be possible, given that the ECU studied is a private institution that only treats cases of low-to-medium complexity. Another limitation of this study was that the diagnoses were determined from the records, which may ultimately not have been accurate. Unfortunately, it was not possible to conclude whether the associations identified among patients who received opioids were due to the drug or to the severity of the headache. However, the sample size was robust and, hence, this study may form a source for new hypotheses about emergency care for patients with headache.

Nonspecific headache and migraine were the reasons for the high rate of spontaneous demand for emergency care. The treatment provided was adequate for the majority of consultations. There was excessive use of opioids, contrary to the recommendations of the Brazilian Headache Society and the International Headache Society ${ }^{2,8}$. However, similar conduct, and with even higher rates of opioid use, is also found in the American population, where a substantial proportion of headache specialists are dissatisfied with the treatment offered by emergency services ${ }^{8}$. Lower rates of opioid use are found in centers of education', which highlights the role of continuing medical education in achieving better acute therapeutic management of headache as well as in prophylaxis planning after discharge.

\section{REFERENCES}

1. Queiroz LP, Silva Junior AA. The prevalence and impact of headache in Brazil. Headache. 2015 Feb 6;55 Suppl 1:32-8. https://doi. org/10.1111/head.12511

2. Speciali JG, Kowacs F, Jurno ME, et al. Protocolo nacional para diagnóstico e manejo das cefaleias nas unidades de emergência do Brasil - 2018. Academia Brasileira de Neurologia, Departamento Cientifico de Cefaleia Sociedade Brasileira de Cefaleia; 2018. Available from: https://sbcefaleia.com.br/images/file\%205.pdf

3. Burch R, Rizzoli P, Loder E. The prevalence and impact of migraine and severe headache in the United States: figures and trends from government health studies. Headache. 2018 Apr;58(4):496-505. https://doi.org/10.1111/head.13281

4. Oliveira AB, Queiroz LP, Rocha-Filho PS, et al. Annual indirect costs secondary to headache disability in Brazil. Cephalalgia. 2020 May;40(6):597-605. https://doi.org/10.1177/0333102419889357

5. Barbetta PA. Estatística aplicada às Ciências Sociais. 6ed. Florianópolis: UFSC; 2006. 320p.

6. Bigal M, Bordini CA, Speciali JG. Headache in an emergency room in Brazil. São Paulo Med J. 2000 May 4;118(3):58-62. https://doi. org/10.1590/S1516-31802000000300002

7. Doretti A, Shestaritc I, Ungaro D, et al. Headaches in the emergency department - a survey of patients' characteristics, facts and needs.
J Headache Pain. 2019 Nov 5;20(1):100. https://doi.org/10.1186/ s10194-019-1053-5

8. Minen MT, Ortega E, Lipton RB, Cowan R. American headache society survey about urgent and emergency management of headache patients. Headache. 2018 Oct;58(9):1389-96. https://doi.org/10.1111/ head.13387

9. Young N, Silverman D, Bradford H, Finkelstein J. Multicenter prevalence of opioid medication use as abortive therapy in the ED treatment of migraine headaches. Am J Emerg Med. 2017 Dec;35(12):1845-9. https://doi.org/10.1016/j.ajem.2017.06.015

10. McCarthy LH, Cowan RP. Comparison of parenteral treatments of acute primary headache in a large academic emergency department cohort. Cephalalgia. 2015 Aug;35(9):807-15. https://doi. org/10.1177/0333102414557703

11. Friedman BW, Irizarry E, Solorzano C, et al. Randomized study of IV prochlorperazine plus diphenhydramine vs IV hydromorphone for migraine. Neurology. 2017 Nov 14;89(20):2075-82. https://doi. org/10.1212/WNL.0000000000004642

12. Bonafede M, Wilson K, Xue F. Long-term treatment patterns of prophylactic and acute migraine medications and incidence of opioid-related adverse events in patients with migraine. Cephalalgia. 2019 Aug;39(9):1086-98. https://doi.org/10.1177/0333102419835465 